\title{
The Influence of Packaging Towards The Purchase Decision of Travel Packages in Bale Seni Barli-Kota Baru Parahyangan
}

\author{
Pengaruh Packaging Terhadap Keputusan Pembelian Paket Wisata Seni di Bale \\ Seni Barli-Kota Baru Parahyangan
}

\author{
Micky Andrea Yunus \\ Indonesia University of Education \\ Bandung, West Java \\ Email: mickyandrea30@gmail.com
}

\begin{abstract}
West Java has many potential tourist attractions, began to develop at this time, such as natural attractions, artificial, cultural, culinary, and special interest. One tourist attraction that develop nowadays is art tourist destination. Its development can be seen in Bandung, Bandung Regency, and West Bandung Regency. Bale Seni BarliKota Baru Parahyangan is one of the art tourist destination in West Bandung Regency, this destination offers a variety of activities which is workshop for tourists. . In order to increase the visitor, the management of Bale Seni Barli-Kota Baru Parahyangan offers a tour packages (packaging) with the main target are education institutions such as kindergarten, elementary, junior high, and high school. Related to the matter so that the research about the influence packaging towards the purchase decision of tour packages to student tourists, in order to obtain findings on the effect of packaging consisting of or demand generators include attractions, provide value to the customer, consistent quality and compatibility, be well planned and coordinated, distinctive customer benefits, and covers all the details on purchasing decisions tour packages to student travelers Bale Seni Barli-Kota Baru Parahyangan. The research used descriptive verification type and the method used is an explanatory survey using an ordinal scale.
\end{abstract}

The population in this research are educational institutions with the sample size using the formula of Slovin, thus obtained a sample of 42 respondents. The sampling technique used is sample random sampling and data analysis technique used is multiple regression analysis. Based on the results of the variables studied, showing that the effect of packaging on purchase decisions outbound tour packages for 79,9\%, while the remaining 20,1\% is influenced by other variables not examined in this study, such as the quality of products and promotions.

Keywords—packaging,

purchase decision, tour packages

\section{INTRODUCTION}

Tourism has become one of the largest industries in the world, provide of employment as well as its role in the world economy continues to increase. Tourism as an industry of invisible export has an impact on the effect of multidimensional, such as creating jobs, reducing poverty, improving the economy of a country or region to be a priority for the national economy, as well as the other industries, such as handicraft industry, lodging, and transportation.

Art tours are included in the category of special interest tours. Art tourism has at least two definitions, the first point of view takes from its cultural side, such as the placement of statues, monuments, and/or murals or art exhibition for cosmetic reasons society and 
the second one is the commercial side where the views of the community or hear some form of artistic expression in the exchange for payment. According to Getz (2010: 9) reveals that there are several arts and cultural attractions are included in the art of travel, namely (1) static art, architecture, and installations; (2) an annual festival or celebration is cultural or ritual; and (3) a creative experience that is education or special interests that brings the educative activities or special interests.

Bale of Barli-Kota Baru Parahyangan is the alternative tourist attraction in West Bandung regency located in Kota Baru Parahyangan. Bale Seni Barli Kota Baru Parahyangan is one of special interest tours that focused on the promotion and it offers various art activities. Bale Seni Barli Kota Baru Parahyangan is one of particular interest in this regard included in the travel category of art. With the packages that are offered, Bale Seni Barli is expected to attract tourists to come and buy tour packages. It can influence purchase decision and be more consideration for tourists to match the needs with the desire, and to see how effective the package in order to add the value of the activities to the tourists.

\section{LITERATURE REVIEW}

\section{A. Concept of Packaging}

The marketing mix is part of the marketing activities that have an important role in influencing consumers to buy products or services offered. Tjiptono (2011: 39) argues that Marketing Mix is a set of tools that can be used to establish the characteristics of the services offered to tourists. Packaging in many ways is part of a marketing orientation and a way to produce and meet the needs of tourists through service facilities. Packaging is very customer-oriented, its satisfies customer's needs that are varied, including the desire of the tourists in a package and is based on the demand from tourists itself. According Middleton and Clarke (2001: 124), The relationship between the tourism product and packaging to form a bundle that consists of components measurable and immeasurable that make up an activity at a tourist attraction as a destination attractions, destination facilities and services, accessibility, images of the destination, and the price to the consumer.

The success of packaging in the tourism industry must be supported by a variety of factors that support and provide benefits not only for tourists but also for tourism organizations that has been made. According to Morrison (2010: 404) there are five factors that play a role in increasing the use of the package as a marketing tool services in the tourism industry, including the smooth pattern of business, improve profitability, help marketing strategies segmenting, help products, the relationship between the travel hospitality and travel organization. From various dimensions of packaging according to the experts, the researcher will refer to the theory proposed by Morrison (2010: 417) because these dimensions is appropriate with the conceptual travel packages art on the research's object. These dimensions consist of attraction or demand generators, value, planning and coordination, consistent quality and compatibility and covers all the details.

\section{B. The Concept of Purchase Decision}

A decision involves a choice between two or more alternative actions (behavior). Purchase decision is the process by which buyers choose one of several options based on product or brand to be consumed. Business buyers usually face a more complex purchase decision of the end consumer. Purchasing often involve large amounts of money and the interaction between people who shared level in the organization of the buyer. In business buyer of the purchase processing is more complicated, business buyer require a longer time to make decision. Business buyer's behavior is the behavior of the purchasing organizations that buy goods and services that being used in the production of order of products and services sold, rented, or supplied to other profit (Kotler and Armstrong, 2012: 201). 


\section{HYPOTHESES RESEARCH}

Hypothesis is a tentative conclusion that must be verified or tentative proposition can be said about the relationship between two or more variables (Masyhuri and Zainuddin, 2011: 142). Hypotheses usually accepted as a temporary statement as true as it was and is a guide working in the verification (Ikbar, 2012: 141) or in the form of repetition of the problem statement with weighting prediction research related to the results of a study (Suharsaputra, 2012: 60). Based on the understanding about hypothesis above, then the researcher compose this hypothesis as follows:"There is a significant relationship between attractions or demand-generators, provide value to the customer, consistent quality and compatibility, be well-planned and coordinated, provide distinctive benefit, covers all the details towards purchase decision in Bale Seni Barli-Kota Baru Parahyangan.

Based on the theories that have been put forward, the proposed hypothesis should be proven through research. Research in formulating a hypothesis supported by some of the premise as follows:

1. The tour package is one of the factors that create the visitor experience for tourists. Arsenault and Gale (2004: 21)

2. Package has implications for the tourists' consideration to travel. Rewastrakunphaiboon and Oppewal (2004: 183)

3. The tour package is one effective way of dealing with potential travelers. Tourism organizations should develop a package of tourism attractions and its facilities. Kotler, Bowen and Makens (2006: 752)

4. Package is the first thing that becomes the consideration of travelers concerning the product and it could change their decision. Kotler and Keller (2008: 20)

Based on the premise above, the researcher hypothesized that there is a significant between the packaging consisting of include attractions or demand generators, provide value to the customer, be well planed and coordinated, offer consistent quality and compatibility among elements, provide a distinctive customer benefits, and covers all the details on purchase decision in Bale Seni Barli-Kota Baru Parahyangan on student tourists.

\section{RESEARCH METHODOLOGY}

The unit of analysis in this study is 42 student tourists who purchased travel art packages in Bale Barli-Kota Baru Parahyangan. Based on the period of the study research method that is involves collecting sample data set of the population carried out only one time and in a period of less than one year, the research method used is cross sectional method (Sugiyono, 2010: 5) Survey method is being used to collect information on the part of the population with the aim to find out what they thought about the object itself.

The questionnaire contains questions and statements concerning the characteristics of respondents have been developed to measure variables packaging and purchase decision in Bale Barli-Kota Baru Parahyangan. Instruments are divided into four sections. Part I consists of 7 questions about demographic characteristics of respondents, i.e. gender, age, region of origin, the last education, employment, occupation, income per month. Part II consists of 5 parts of respondent experiences. Part III consists of 18 questions to measure packaging consisting of attractions or demand generators, provide value to the customer, be well planed and coordinated, offer consistent quality and compatibility among elements, provide a distinctive customer benefits, and covers all the details that they (respondents) feel by using a Likert scale with the approval level ranging from (1) "Strongly Disagree" to (5) "Strongly Agree". Part IV consists of 10 questions to measure purchase decision. The survey was conducted within a month with the help of staff Bale of Barli-Kota Baru Parahyangan. The positive response and good rating has been obtained during the survey. A total of 50 questionnaires were collected. The data encoding process performed on Statistical Product and Service Solutions (SPSS) Version 20. Reliability 
testing carried out separately and the results showed that the instrument used reliable with Cronbach alpha coefficient of 0.743 for packaging, and 0.731 for purchase decision.

\section{RESULT RESEARCH}

\section{A. Profile of Respondents}

Based on descriptive statistics, 57.1\% (n $=100)$ of the respondents were women compared with men who only $42.9 \%$. If by age group, $52.3 \%$ were aged between $31-40$ years. Most tourists who purchased travel packages in Bale Barli-Kota Baru Parahyangan is $66.6 \%$ of graduates $\mathrm{S} 1$ and $\mathrm{S} 2$ with the remaining $33.4 \%$. If seen from the area of origin of tourists, $23.8 \%$ came from Jakarta, 7.1\% came from Tangerang, $4.7 \%$ came from Bekasi, and $4.7 \%$ from other cities. Rating based jobs, the majority of respondents civil servants $(71.4 \%)$, which consists of the post of teachers, principals and administrative staff, while the remaining $28.6 \%$ is private employees. Based on income per month, a total of $42.8 \%$ found in the range of $\mathrm{Rp} 3,000,000$ to $\mathrm{Rp} 5,000,000$ followed by $30.9 \%$ in the range of more than $\mathrm{Rp5}, 000,000$ and the remaining $26.3 \%$ in the range of $R p 1,000,000$ to $R p 3,000,000$. Based on the reason tourists choose Bale of Barli-Kota Baru Parahyangan, 42.9\% opted for the attraction and promotion given by $38.1 \%$, the quality of services in third with a gain of $33.3 \%$, followed by facilities by 25 , $3 \%$, and the final price, location, as well as the diversity of the products get the same value, namely $28.6 \%$.

TABLE 1 : Mean the decision of packaging Bale Seni Barli-Kota Baru Parahyangan

\begin{tabular}{|l|l|l|}
\hline Variable & Mean & $\begin{array}{l}\text { Stand } \\
\text { ard } \\
\text { Deviat } \\
\text { ion }\end{array}$ \\
\hline Attractions or Demand-generators (ADG) \\
\hline $\begin{array}{l}\text { The attractions of travel } \\
\text { packages in Bale Seni } \\
\text { Barli }\end{array}$ & & 0.42 \\
\hline $\begin{array}{l}\text { Duration of the activity in } \\
\text { Bales Seni Barli }\end{array}$ & 3.90 & 0.98 \\
\hline
\end{tabular}

\begin{tabular}{|c|c|c|}
\hline $\begin{array}{l}\text { Clarity guides in providing } \\
\text { guidance to participants }\end{array}$ & 4.14 & 0.95 \\
\hline $\begin{array}{l}\text { The attractions of the } \\
\text { composition of travel } \\
\text { packages activities }\end{array}$ & 3.83 & 0.72 \\
\hline Average & 4.07 & \\
\hline \multicolumn{3}{|c|}{ Provide Value to The Customers (PV) } \\
\hline $\begin{array}{l}\text { The amount of the benefit } \\
\text { received from the travel } \\
\text { package }\end{array}$ & 3.95 & 1.03 \\
\hline $\begin{array}{l}\text { The amount of sacrifice in } \\
\text { monetary/non-monetary } \\
\text { issued }\end{array}$ & 3.88 & 0.99 \\
\hline $\begin{array}{l}\text { The agreement price with } \\
\text { sacrifice issued price }\end{array}$ & 4.16 & 0.93 \\
\hline Average & 3.99 & \\
\hline \multicolumn{3}{|c|}{ Planned and Coordinated (PC) } \\
\hline $\begin{array}{l}\text { The suitability of the } \\
\text { concept package with the } \\
\text { purpose activities }\end{array}$ & 3.59 & 0.96 \\
\hline $\begin{array}{l}\text { Coordination between } \\
\text { elements of the travel } \\
\text { package }\end{array}$ & 3.57 & 0.80 \\
\hline $\begin{array}{l}\text { Consistency of the quality } \\
\text { of the service guide }\end{array}$ & 3.57 & 0.88 \\
\hline Average & 3.57 & \\
\hline \multicolumn{3}{|c|}{$\begin{array}{c}\text { Consistent Quality and Compatibility } \\
\text { (CQC) }\end{array}$} \\
\hline $\begin{array}{l}\text { The safety of the media in } \\
\text { travel package }\end{array}$ & 3.57 & 1.19 \\
\hline Cleanliness of the area & 3.85 & 0.95 \\
\hline $\begin{array}{l}\text { Cleanliness media in the } \\
\text { travel package }\end{array}$ & 3.38 & 0.98 \\
\hline Average & 3.6 & \\
\hline \multicolumn{3}{|c|}{ Distinctive Customer Benefit (DCB) } \\
\hline The diversity of packages & 3.57 & 0.83 \\
\hline $\begin{array}{l}\text { The attractiveness of the } \\
\text { activities }\end{array}$ & 3.57 & 0.96 \\
\hline Average & 3.57 & \\
\hline \multicolumn{3}{|c|}{ Cover All Details (CAD) } \\
\hline $\begin{array}{l}\text { The availability of the } \\
\text { information in purchase } \\
\text { travel packages }\end{array}$ & 3.35 & 1.12 \\
\hline $\begin{array}{l}\text { The availability of media } \\
\text { tools for travel packages }\end{array}$ & 3.73 & 1.28 \\
\hline $\begin{array}{l}\text { The advantages of the } \\
\text { packages in special rate }\end{array}$ & 3.50 & 1.04 \\
\hline Average & 3.52 & \\
\hline
\end{tabular}




\begin{tabular}{|c|l|l|}
\hline $\begin{array}{c}\text { Total average } \\
\text { (Packaging) }\end{array}$ & 3.72 & \\
\hline
\end{tabular}

Source: Data analysis 2014

Based on Table 1, it can be seen that the average score of attractions or demandgenerators ranging from 3.83 to 4.42 , it indicates that the respondents were agree and satisfied with the attractions in Bale Seni Barli (4.42). On provide value to the customers, the respondents believed that the price set by the organizer is appropriate with the sacrifices of the customers. This is consistent with the average score on these items (4.16). Then on consistent quality and compatibility, the respondents feel that the cleanliness of the area is already clean (3.85). While the diversity of packages and the attractiveness of the activities has the same score (3.57). The last one in cover all details, the respondents feel that they are fulfilled with the availability of the media tools (3.73). The recapitulation of responses packaging is presented as follows:

TABLE 2: Summary result of responses packaging in Bale Seni Barli

\begin{tabular}{|l|l|l|l|l|}
\hline No & Subvarible & Score & \multicolumn{1}{|c|}{$\begin{array}{c}\text { Item } \\
\text { Questions }\end{array}$} & $\begin{array}{c}\text { Average } \\
\text { Score }\end{array}$ \\
\hline 1 & $\begin{array}{l}\text { Attractions } \\
\text { or Demand- } \\
\text { Generators }\end{array}$ & 685 & 4 & 171 \\
\hline 2 & $\begin{array}{l}\text { Provide } \\
\text { Value to The } \\
\text { Customer }\end{array}$ & 504 & 3 & 168 \\
\hline 3 & $\begin{array}{l}\text { Planned and } \\
\text { Coordinated }\end{array}$ & 451 & 3 & 150 \\
\hline 4 & $\begin{array}{l}\text { Consistent } \\
\text { Quality and } \\
\text { Compatibility }\end{array}$ & 454 & 3 & 151 \\
\hline 5. & $\begin{array}{l}\text { Distinctive } \\
\text { Customers } \\
\text { Benefit }\end{array}$ & 300 & 2 & 150 \\
\hline 6. & $\begin{array}{l}\text { Cover All } \\
\text { Details }\end{array}$ & 445 & 3 & 148 \\
\hline \multicolumn{2}{|l|}{ Total } & $\mathbf{2 8 3 9}$ & $\mathbf{1 8}$ & $\mathbf{9 3 8}$ \\
\hline
\end{tabular}

Source: Data analysis 2014

The total score ideal (criteria) for all tems are 2780 (if all answer "Strong Agree"). Based on the above table, the scores obtained from the research is 2839 , it can be conclude that the approval rate of the packaging is $75 \%$ from the expectation $(100 \%)$.
TABLE 3: Results of Testing Statistical Hypotheses

\begin{tabular}{|c|c|c|c|}
\hline Hypothesis & Statement & Score & Desciption \\
\hline $\mathrm{H}_{1}$ & $\begin{array}{l}\text { Attractions or } \\
\text { demand- } \\
\text { generators is } \\
\text { positive and } \\
\text { has significant } \\
\text { impact on the } \\
\text { purchase } \\
\text { decision }\end{array}$ & 1.072 & $\mathrm{H}_{01}$ accepted \\
\hline $\mathrm{H}_{2}$ & $\begin{array}{l}\text { Provide value } \\
\text { to the } \\
\text { customer is } \\
\text { positive and } \\
\text { has significant } \\
\text { impact on the } \\
\text { purchase } \\
\text { decision }\end{array}$ & 0.531 & $\mathrm{H}_{02}$ accepted \\
\hline $\mathrm{H}_{3}$ & $\begin{array}{l}\text { Planned and } \\
\text { coordinated is } \\
\text { positive and } \\
\text { has significant } \\
\text { impact on the } \\
\text { purchase } \\
\text { decision }\end{array}$ & 0.524 & $\mathrm{H}_{03}$ accepted \\
\hline $\mathrm{H}_{4}$ & $\begin{array}{l}\text { Consistent } \\
\text { quality and } \\
\text { compability is } \\
\text { positive but } \\
\text { not significant } \\
\text { influence on } \\
\text { the purchase } \\
\text { decision }\end{array}$ & 0.033 & $\mathrm{H}_{\mathrm{a} 4}$ accepted \\
\hline $\mathrm{H}_{5}$ & $\begin{array}{l}\text { Distinctive } \\
\text { customer } \\
\text { benefit is } \\
\text { positive but } \\
\text { not significant } \\
\text { to purchase } \\
\text { decision }\end{array}$ & 0.359 & $\mathrm{H}_{\mathrm{a} 5}$ accepted \\
\hline $\mathrm{H}_{6}$ & $\begin{array}{l}\text { Cover all } \\
\text { details is } \\
\text { positive but } \\
\text { not significant } \\
\text { to purchase } \\
\text { decision }\end{array}$ & 0.203 & $\mathrm{H}_{\mathrm{a} 6}$ accepted \\
\hline
\end{tabular}

Source: Data analysis 2014

There is value Sig. 0.002 on ADG smaller than value probability 0.1 , or the value 0.002 $<0.1$, so that $\mathrm{H}_{01}$ accepted and $\mathrm{H}_{\mathrm{a} 1}$ rejected. Variable ADG has $t_{\text {value }}=3.410$ with $t_{\text {table }}$ $=1.688$. It can be conclude that that the variable ADG has contributed to the purchase decision. Positive value indicates that the variable ADG has a direct relationship to the purchase decision. So we 
can conclude ADG has a significant positive effect on purchase decision.

There is value Sig. 0.005 on PV smaller than value probability 0.1 , or the value 0.005 $<0.1$, so that $\mathrm{H}_{02}$ accepted and $\mathrm{H}_{\mathrm{a} 2}$ rejected. Variable PV has $\mathrm{t}_{\text {value }}=1.690$ with $\mathrm{t}_{\text {table }}$ $=1.688$. So that $t_{\text {value }}>t_{\text {table, }}$ it can be conclude that that the variable $\mathrm{PV}$ has contributed to the purchase decision. Positive value indicates that the variable PV has a direct relationship to the purchase decision. So we can conclude PV has a significant positive effect on purchase decision.

There is value Sig. 0.021 on PC smaller than value probability 0.1 , or the value 0.021 $<0.1$, so that $\mathrm{H}_{03}$ accepted and $\mathrm{H}_{\mathrm{a} 3}$ rejected. Variable PC has $\mathrm{t}_{\text {value }}=1.873$ with $\mathrm{t}_{\text {table }}$ $=1.688$. So that $t_{\text {value }}>t_{\text {table, }}$ it can be conclude that that the variable $\mathrm{PC}$ has contributed to the purchase decision. Positive value indicates that the variable $\mathrm{PC}$ has a direct relationship to the purchase decision. So we can conclude PC has a significant positive effect on purchase decision.

While value Sig. 0.092 on CQC greater than value probability 0.1 , or the value 0.092 $>0.1$, so that $\mathrm{H}_{04}$ rejected and $\mathrm{H}_{\mathrm{a} 4}$ accepted. Variable CQC has $\mathrm{t}_{\text {value }}=0.928$ with $\mathrm{t}_{\text {table }}$ $=1.688$. So that $t_{\text {value }}<t_{\text {table, }}$ it can be conclude that that the variable CQC has not contributed to the purchase decision. Positive value indicates that the variable $\mathrm{CQC}$ has a direct relationship to the purchase decision. So we can conclude CQC has not a significant positive effect on purchase decision.

There is also value Sig. 0.414 on DC greater than value probability 0.1 , or the value $0.414>0.1$, so that $\mathrm{H}_{05}$ rejected and $\mathrm{H}_{\mathrm{a} 5}$ accepted. Variable $\mathrm{PC}$ has $\mathrm{t}_{\text {value }}=0.827$ with $\mathrm{t}_{\text {table }}=1.688$. So that $\mathrm{t}_{\text {value }}<\mathrm{t}_{\text {table, }}$, it can be conclude that that the variable DC has not contributed to the purchase decision. Positive value indicates that the variable $\mathrm{DC}$ has a direct relationship to the purchase decision. So we can conclude DC has not a significant positive effect on purchase decision.

While value Sig. 0.300 on CAD greater than value probability 0.1 , or the value 0.300
$>0.1$, so that $\mathrm{H}_{06}$ rejected and $\mathrm{H}_{\mathrm{a} 6}$ accepted. Variable CAD has $\mathrm{t}_{\text {value }}=1.051$ with $\mathrm{t}_{\text {table }}$ $=1.688$. So that $t_{\text {value }}<t_{\text {table, }}$ it can be conclude that that the variable CAD has not contributed to the purchase decision. Positive value indicates that the variable CAD has a direct relationship to the purchase decision. So we can conclude CAD has not a significant positive effect on purchase decision.

\section{CONCLUSIONS AND RECOMMENDATIONS}

Based from the above processing and the research that has been done in the previous chapter, in this final section the authors suggest several conclusions and suggestions. In summary it can be conclude as follows:

1. The variety of responses Bale of Barli about packaging that is consists of attractions or demand-generators, provide value to the customer, offer consistent quality and compatibility among elements, be well planned and coordinated, distinctive customer benefits, and covers all the details, then who gets the highest ratings are the attractions or demand- generators, it is due to the attraction offered by Bale of Barli different from other tourist attraction, which carries a special theme that is arts and travel packages offered are varied and. While the lowest score is distinctive customer benefit, it is because the lack of supplies media required for travelers as a support activity art tourism in Bale Barli and also the diversity of tour packages offered.

2. Purchase decision Bale travel packages in Barli-Kota Baru Parahyangan in general based continuum line is on the high level. Purchase decisions assessed by the selection of products / services, number of purchases, purchasing requirements, terms and time of purchase, and payment methods. From these four indicators, selection of products / services get the highest score, it is because the uniqueness of tour packages offered by Bale of Barli supported by good quality travel packages as well as safe for tourists. 
3. This research found that there is significant influence between packaging towards purchase decision of Bale of Barli simultaneously and / or partially. Attractions or demand-generators, provide value to the customer, offer consistent quality and compatibility among elements, be well planned and coordinated, distinctive customer benefits, and covers all the details. So it can be concluded that the higher the score of packaging, the higher purchase decision that educational institutions made.

\section{REFERENCES}

[1] Arsenault, Nancy, Gale, Trace. "Defining Tomorrows Tourism Product: Packaging Experience." Canadian Tourism Commision, 2004.

[2] N. Bresler. "Decision Factors for Domestic Packages Tours-Case Study of A Region in South Africa." Turizam.

[3] B. Alma. "Manajemen Pemasaran dan Pemasaran Jasa," edisi revisi, Alfabeta, Bandung, 2008.

[4] K. Elissa, "Title of paper if known," unpublished.

[5] C. Antonia, A. Pimpao. "Decisionmaking Process of Portugese Tourist Traveling to South America and Africa." Faculty of Economic, University of Algarve, Fasro, Portugal, 2008.

[6] S. Sari Purnama Dewi. "Pengaruh packaging Terhadap Proses Keputusan Pembelian Paket Wisata Olahraga Rafting Arus Liar. "Manajemen Pemasaran Pariwisata UPI. Bandung, 2013.

[7] A. Firdaus. "Metode Penelitian. "Alfabeta. Tangerang Selatan. 2012

[8] D. Getz. "Arts, Culture, and Tourism:Partnerships and Challenges. "University of Calgary, Canada, 2010.

[9] P. Kotler and G. Amstrong. "Principles of Marketing $12^{\text {th }}$ Edition." New Jersey : Prentince Hall, 2009.
[10] P. Kotler and K. Lane Keller. Marketing Management $12^{\text {th }}$ Edition. New Jersey : Prentince Hall, 2009.

[11]

"Marketing Management $14^{\text {th }}$ Edition." New Jersey : Prentince Hall, 2012.

[12] P. Kotler, T. Bowen,J. Makens. "Marketing for Hospitality and Tourism $4^{\text {th }}$ Edition". New Jersey : Prentince Hall, 2006

[13] P. Kotler, and G. Amstrong. "Principles of Marketing $12^{\text {th }}$ Edition." New Jersey : Prentince Hall, 2009.

[14]

"Principles of Marketing $14^{\text {th }}$ Edition." New Jersey : Prentince Hall, 2012.

[15] Masyhuri and M. Zainuddin. "Metodologi Penelitian: Pendekatan Praktis dan Aplikasi." Bandung: Refika Aditama, 2011.

[16] V.T.C. Middleton and J. Clarke. "Marketing in Travel and Tourism."Butterworth-Heineman : Oxford, 2001.

[17] Mullins, John, and O. Walker Jr. "Marketing Management." McGraw-Hil, 2010.

[18] A. Morrison. "Hospitality and Travel Marketing $3^{\text {rd }}$ Edition." Delmar : New York, 2002.

[19] Travel Marketing $4^{\text {th }}$ Edition." Delmar : New York, 2010.

[20] U. Narimawati. "Riset Manajemen Sumber Daya Manusia." Jakarta: Agung Media, 2007

[21] H. Ratih. "Bauran Pemasaran dan Loyalitas Konsumen." Bandung : Alfabeta, 2010.

[22] Sugiyono. "Metode Penelitian Kuantitatif Kualitatif dan $R \& D$." Alfabeta : Bandung, 2011.

[23] "Metode Penelitian Kuantitatif Kualitatif dan R\&D." Alfabeta : Bandung, 2013.

[24] U, Suharsaputra. "Metode Penelitian." Bandung: PT. Refika Aditama, 2012. 
[25] S. Arikunto. "Prosedur Penelitian: Suatu Pendekatan Praktek (Edisi Revisi 5)." Jakarta : PT. Rineka Cipta, 2009.

[26] F, Tjiptono. "Pemasaran Jasa." Jawa Timur: Bayumedia, 2011.

[27] U. Sekaran. "Research Method Of Business." Jakarta : Salemba Empat, 2006.

[28] H. Umar. "Metode Penelitian Untuk Skripsi dan Tesis Bisnis Edisi Kedua." Jakarta : Rajawali Pers, 2009.

[29] H. Umar. "Metode Riset Bisnis." Jakarta: PT. Gramedia Pustaka Utama, 2010.

[30] Anonim. "Undang-undang No. 10 Tahun 2009 Tentang Kepariwisataan", 2009.

[31] T. Wijaya. "SPSS 20 Untuk Olah dan Intepretasi Data. Cetakan ke-5." Yogyakarta. Cahaya Atma Pustaka. 2012.

[32] H. Al Rasyid. "Teknik Penarikan Sampel dan Penyusunan Skala." Bandung: Program Studi Ilmu Sosial Bidang Kajian Utama Sosiologi Antropologi Program Pasca Sarjana UNPAD. Bandung, 1994.

[33] Kuntjojo. "Metode Penelitian." Universitas Nusantara PGRI:Kediri, 2009.
[34] W. Rewatrakunphaiboon and $\mathrm{H}$. Oppeewal. "Effect of Holiday Packaging on Tourist Decision Making : Some Prelimenary Result." School of Management University of Survey \& Departement of Marketing, Monash University, 2004.

[35] W. Rewatrakunphaiboon. "Effect of Package Holiday Information Presentation on Destination Choice." Journal of Travel Research. 2008.

[36] N. Setiawan. "Diklat Metodologi Penelitian Sosial Parung Bogor, 25-28 Mei 2005 Teknik Sampling." Inspektorat Jenderal Departemen Pendidikan Nasional Universitas Padjajaran, 2005.

[37] K. Smith. "Distribution Channel for Event : Supply and Demand-side Persective." Victoria University : New Zealand, 2007.

[38] L. Sukmawati. "Pengaruh Kinerja Bauran Promosi Terhadap Keputusan menggunakan Paket Outbound di Ciwangun Indah Camp." Manajemen Pemasaran Pariwisata UPI. Bandung, 2013 